\title{
ARTIGO
}

\section{Fome de ler: a leitura em movimento como processo de inclusão social ${ }^{1}$}

\author{
Hungry for reading: reading as a \\ process of social inclusion
}

Else Benetti Marques VÁLIO²

RE S U M O

Propõe-se uma investigação com o objetivo de conhecer os interesses de leitura dos habitantes de Campinas que não freqüentam a Biblioteca Pública. Para tanto, foi feito um levantamento em mapas de zoneamento da cidade, a partir dos catálogos de usuários, a fim de diagnosticar quais regiões são mais carentes de um trabalho com a leitura. Os dados da pesquisa foram coletados por meio de um Roteiro de Entrevista Estruturada. Através de uma amostra estratificada, foram entrevistados 880 moradores, com o propósito de conhecer os interesses de leitura desses possíveis leitores residentes nos 40 bairros selecionados. Os resultados da pesquisa serviram como subsídios no traçado das diretrizes para o estabelecimento de uma Política da Secretaria Municipal de Cultura que visa reestruturar a Rede de Biblioteca Pública de Campinas, implantando bibliotecas setoriais com acervos adequados às necessidades e interesses dos leitores. O projeto viabilizou uma proposta de programa de incentivo à leitura para moradores que não tiveram acesso aos bens culturais dos letrados e, portanto, a alguns dos meios de exercer o direito à sua cidadania.

Palavras-chave: biblioteca pública, interesses de leitura, seleção de acervo, aquisição de acervo.

\footnotetext{
${ }^{1}$ Artigo elaborado a partir do Projeto de Pesquisa "Implantação de Rede de Biblioteca Pública: uma proposta de Política Educacional de promoção de leitura para moradores de bairros periféricos de Campinas", financiado pelo Programa de Políticas Públicas/FAPESP.

2 Professora Titular, Programa de Pós-Graduação em Ciência da Informação, Mestrado em Ciência da Informação, Pontifícia Universidade Católica de Campinas. Participaram também desta pesquisa a Coordenadora da Rede de Bibliotecas Públicas Gláucia Mollo Pécora e os Bolsistas: Ana Jandira Raphael; Antônio Carlos Ramos da Silva Júnior; Cláudia Regina M. L. Cerri; Gisele Falcari; Simone Panonto e Vangri de Oliveira Camargo.
} 


\section{A B S T R A C T}

The investigation objective was to find out the reading interests of the population segment, in Campinas, that does not use the Public Library. For this purpose, zone maps of the city were assembled from users' catalogues, in order to determine which regions were the most deficient in reading facilities. The investigation data were collected by means of a structured interview guide. Interviews were conducted with 880 residents, chosen randomly, from 40 selected suburbs with a view to learn their reading interests. The results were used in outlining the strategies to establish a policy for the Council's Culture Bureau in order to restructure the Campinas' Public Library system, implanting regional Libraries with collections that meet the aspiration and interests of the prospective readers. So doing, made viable a proposal for a reading incentive program aiming at residents deprived of easement of access to the literate culture and, therefore, deprived of an instrument to exercise their citizenship.

Key words: public library, reading interests, collection selection, collection acquisition.

\section{N T R O D U Ç Ã O}

O nosso interesse em formar leitores, tendo como meta a inclusão social destas pessoas para o exercício pleno de cidadania, já vem desde a década de 1970. No entanto, a possibilidade de melhor concretizar esse desejo surgiu a partir de um Programa de Políticas Públicas editado, em primeira versão, pela Fapesp. Pensando nos moradores de Campinas que não têm oportunidades de leitura, pois esta cidade com quase um milhão de habitantes (968.172 habitantes, censo de 2000), dividida em 850 bairros, tem uma rede de bibliotecas públicas de apenas quatro bibliotecas.

Em vista disto, implantamos este Projeto de Pesquisa (vide rodapé 1 e 2), com o objetivo de disponibilizar dois ônibus-biblioteca com acervo pertinente aos interesses dos futuros usuários e de oportunizar a leitura de textos literários e informativos aos moradores dos bairros periféricos de Campinas. Assim esta pesquisa é um projeto de "intervenção sócio pedagógica" (BAPTISTA, 2000) àqueles que não puderam usufruir da oportunidade de leitura durante a vida escolar (ou nem este direito tiveram).

Em nosso entender, todos, neste país, tem direito à Educação para a cidadania (RIBEIRO, 2002).

Portanto, se nosso objetivo é entender a leitura como um processo de inclusão social, como direito de exercício de cidadania, por meio da Leitura em movimento (denominação dada pela equipe ao Projeto), precisamos inicialmente explicitar o que compreendemos por cidadania:

Há também, por parte de muitos filósofos que refletem sobre a constituição do Estado-nação, ao qual está vinculada a noção moderna de cidadania, um reconhecimento de que a educação é um bem que deve estar acessível a todos os indivíduos, de modo a tornar possíveis as condições para o exercício de uma efetiva cidadania (RIBEIRO, 2002, p.115).

Mais adiante, Ribeiro conceitua educação, o que tomamos como nosso, para fins deste trabalho, o mesmo conceito: 
Uma concepção ampliada de educação abrange os processos formativos que se realizam nas práticas sociais relacionadas às diferentes manifestações de convivência humana que ocorrem na vida familiar, no trabalho, no lazer, na participação política e no aprendizado escolar (RIBEIRO, 2002, p.115).

A educação escolar, neste olhar de Ribeiro, é o momento de acesso à "constituição da cidadania". Não podendo estudar, as pessoas sofrem um processo de exclusão social, que é nomeado por Castel (1997) de "desfiliação social". Este autor demonstra que não é uma exclusão total porque o cidadão, mesmo assim, permanece incluído no contexto social.

Baptista (2000, p.1), professora da Universidade Portucalense, Porto, afirma que “(...) os fenómenos de exclusão não se referem a situações conjunturais mas a estados duráveis de privação de direitos de cidadania".

A questão social, com relação à globalização e a deterioração dos postos de trabalho, estudada por Castel (1998), em uma perspectiva histórica, é mostrada como "(...) um processo central, comandado pelas novas exigências tecnológicas-econômicas da evolução do capitalismo moderno". Há, portanto, com respeito às relações de trabalho uma ausência de estabilidade daqueles que têm emprego e daqueles desempregados, tornando-se estes últimos participantes da exclusão social e aqueles candidatos a engrossarem essa situação de "desfiliação".

São dignas de nota e encorajadoras as palavras que transparecem na fala de Castel (2001), quando fez uma intervenção na Conférence sur L'avenir du travail, de emploi et de la proctention sociale

II me semble qu'on peut commencer aujourd'hui à argumenter ce second type d'hypothèse, c'est-à-dire que la croissance économique, si elle se confirme, et les évolutions démographiques prévisibles à court terme peuvent changer le rapport entre l'offre et la demande sur le marché du travail. II n'est pas utopique d'envisager un retour à des formes nouvelles de plein emploi.

Analisando a fala de Castel, esta hipótese poderá acontecer, mas, a nosso ver, é bem possível que uma nova estrutura das relações de trabalho se realize também por meio das instituições cooperadas, ou seja, no modo de cooperativas.

Já que ainda não chegamos a esse futuro, projetado por Castel, a escola tem que continuar sendo a providente da constituição de cidadania burguesa, "(...)que se assenta sobre os princípios de liberdade e igualdade". Se assim for, teremos que dizer com Ribeiro que:

Em base a estes princípios, a sociedade deveria oferecer, principalmente através da educação básica, condições igualitárias para que os indivíduos tivessem acesso ao exercício de uma cidadania ativa. Contraditando com este discurso, o Estado burguês cria artifícios que inviabilizam a universalização de uma educação pública articulada aos interesses dos segmentos sociais e culturais tradicionalmente excluídos do conceito e das práticas que implicam a cidadania (RIBEIRO, 2002, p.124).

Como isto não vem acontecendo em nosso país, pois $17,8 \%$ da população brasileira é analfabeta, as políticas públicas precisam ser endereçadas a esse fazer da escola de inclusão e ao fazer dos projetos que visualizam uma sociedade de "filiados".

Se o percentual de analfabetos corresponde a $17,8 \%$, o que dizer daqueles que podem 
decodificar os signos lingüísticos, mas não podem interpretar o que lêem?

Há uma separação nítida entre trabalho manual e intelectual, como se observa nas falas dos sujeitos: 'Leio o necessário quando tenho tempo, às vezes eu vejo os documentos e as notas do material muito rápido, mas tenho que prestar atenção para não colocar coisas no lugar errado'. Nesse caso, o ato de ler serve apenas como um decodificador do tipo de material recebido no local de trabalho visando a sua organização, apenas isso (CASTRO, 1999, p.94).

Temos, então, dois níveis de cidadãos que não lêem: os analfabetos e os alfabetizados funcionais. É com este segundo nível, que tem "o conceito sócio-cultural de letramento" (BARBOSA, 1999, p.1), que pretendemos transformar os cidadãos também em leitores, pensando a biblioteca pública como uma das instituições que pode providenciar uma intervenção social.

\section{BIBLIOTECAS PÚ BLICAS}

Para melhor entendermos a leitura como um processo de inclusão e um modo de saciarmos a fome de ler, faz-se importante analisarmos o histórico da Biblioteca Pública no Brasil, ou seja, as oportunidades de acesso ao livro como um direito de cidadania.

Na segunda metade do século XVI, com a instalação do Governo-Geral, na Bahia, e com a vinda dos Jesuítas, os primeiros livros chegaram ao Brasil nas bagagens desses religiosos. Para atender a demanda de acervo, tiveram que solicitar à Metrópole remessa de livros de diversos gêneros. Pouco a pouco os acervos foram aumentando e tornaram-se de uso parti- cular dos jesuítas, não havendo no país nenhum outro tipo de biblioteca ou livraria, que promovesse a formação de leitores, pois ninguém mais se interessava em lê-los, uma vez que mais de $80 \%$ da população era constituída de analfabetos (inclusive o próprio colonizador) (VALIO, 1990).

As bibliotecas conventuais existiram até a segunda metade do século XVIII (1759), quando da expulsão dos jesuítas por Pombal. Depois da expulsão, os livros foram usados para embrulhar mercadorias ou permaneceram em depósitos, estragando-se (LIMA, 1974, p. $38,49,73)$.

A primeira Biblioteca Pública, com o objetivo de atender aos cidadãos em geral, foi fundada em 1811, na Bahia. Até então, as bibliotecas conventuais, principalmente dos Jesuítas, cuja missão era ensinar as primeiras letras aos alunos do Brasil Colônia e prover as necessidades de leitura dos religiosos, sendo, portanto, consideradas como privadas.

Embora tenha sido criada para "promover a instrução do povo" (SUAIDEN, 1980, p. 6), a Biblioteca Pública da Bahia iniciou-se sem nenhuma verba ou local específico destinado a ela, pois deveria funcionar com seus próprios recursos. Assim, a primeira Biblioteca Pública brasileira teve que se manter por meio de doações de pessoas interessadas em prover os recursos financeiros para a aquisição de acervo, de mobiliário, de materiais necessários para os serviços biblioteconômicos e, também, para o pagamento dos recursos humanos. Para que pudesse concretizar o seu funcionamento, ela foi inaugurada no Convento dos Jesuítas, mudando de local por várias vezes.

É interessante enfatizar que até a década de 1970, a maioria das bibliotecas públicas não possuía um local efetivo para o seu funcionamento. Não havia uma política de promoção das bibliotecas públicas. Somente depois de um século e meio de existência das bibliotecas públicas, é que elas passaram a ter uma sede própria. Até então nenhuma verba esteve a elas 
destinada para esse fim, não havendo, portanto, nenhuma preocupação em endereçar Políticas Públicas para o bom funcionamento dessas bibliotecas, cuja missão é a instrução do povo.

A biblioteca pública, mantida pelo governo (sic), tem por objetivo primordial preservar e difundir conhecimento, principal-mente no que se refere à cultura local, $\mathrm{e}$ dentre todos os tipos de bibliotecas é a única que possui realmente características de uma instituição social, tanto pela amplitude de seu campo de ação como pela diversificação de seus usuários. É um centro de educação permanente para a pessoa (SUAIDEN, 1995, p. 20).

Vejamos, então, "instrução do povo" e "educação permanente para a pessoa" pode significar contribuir para a constituição da cidadania, ou seja, segundo Araújo (1992, p. 69) “(...) é o conceito que expressa o conjunto de direitos e deveres do indivíduo no contexto da sociedade". Direito, portanto, ao acesso à informação, aos bens culturais, o que é o mesmo que dizer ter a oportunidade de ser usuário de uma biblioteca pública, onde poderá adquirir esses conhecimentos. Essas oportunidades podem ser providenciadas pelo Estado ou pelo setor privado, especificamente pelo primeiro, através de Políticas Culturais.

O papel do Estado exercido nas políticas culturais varia de país para país, seja ele pertencente aos desenvolvidos ou àqueles em desenvolvimento (SILVA, 1993, p. 43). A participação estatal ou privada nas políticas culturais vai depender da tradição de cada país e da competência de cada governo em compreender como prioridade a aquisição, pelos cidadãos, dos bens culturais, assim como de serem partícipes do processo de criação da cultura.

Entretanto, sob essa perspectiva do que seja política cultural "Ocorre que entre o que é realizado e o que é ideal realizar, existe a dificuldade do como fazer" (SILVA, 1993, p. 46).

Com relação ao que se espera do poder público, neste início do novo milênio, destacamos uma nova visão, revelada no final de 1990, que enfoca três conceitos: o de governabilidade, o de agenda pública e o de políticas públicas. Quanto ao primeiro e terceiro conceitos, eles não são novos, mas foram explicados com outras categorias conceituais. O processo de globalização, o surgimento crescente de novas tecnologias, os novos padrões econômicos e produtivos fizeram com que do Estado fossem exigidas novas posturas, pois um novo conceito de cidadania também se faz presente.

Assim, quanto ao segundo conceito, referente à agenda pública, aprendemos que

(...) cuando el estado era dueño del $80 \%$ de la inversión, las empresas productivas y los servicios sociales y el gobierno desempeñaba un rol tan preponderante en la sociedad, la gente votaba por los programas de gobierno que le ofrecian los distintos partidos políticos y no se hablaba de que el govierno tuviera que interpretar y satisfacer una agenda ciudadana (UNIVERSIDADE DO CHILE, 1999).

Portanto, no Chile e no Brasil, a obrigação do governo, até então, era administrar os recursos para a implantação e execução dos programas governamentais. Hoje, entretanto, espera-se que se cumpra uma agenda de políticas públicas, o que supõe o surgimento do "(...) principal instrumento de articulación entre la acción del gobierno y las demandas de la ciudadanía, por lo menos en cinco planos" (UNIVERSIDADE DO CHILE, 1999).

Os cinco planos referidos são: do ponto de vista estratégico; do ponto de vista institucional; do ponto de vista político; do ponto de vista da sociedade civil e do ponto de vista "valórico". 
Em todos os cinco planos, podemos incluir as políticas sociais, abrangidas pelas políticas culturais, as quais têm como objetivo a instrução dos povos.

Em âmbito internacional, a preocupação com a instrução dos povos é da competência da Organização das Nações Unidas para a Educação, Ciência e Cultura (Unesco), que é o órgão responsável estimulador das políticas culturais, incentivando a publicação de livros, dando apoio financeiro à implantação de redes e sistemas de bibliotecas públicas.

A biblioteca pública representa, para a Unesco, "(...) uma força em prol da educação, da cultura e da informação, sendo um instrumento indispensável para promover a paz e a compreensão entre povos e nações" (SUAIDEN, 1980, p. 39).

No Brasil, a primeira instituição que desenvolveu um projeto com a intenção de criar um sistema de bibliotecas públicas foi o Instituto Nacional do Livro (INL), aprovado pela Unesco em 1972, então denominado de Projeto Piloto para o desenvolvimento de Bibliotecas Públicas integradas em programas de educação de adultos e alfabetização no Estado de Pernambuco.

Nesse projeto a colaboração da Unesco foi materializada com a vinda de especialistas estrangeiros, com a remessa de equipamentos, além de bolsas de estudos para bibliotecários brasileiros estagiarem em países com sistemas de bibliotecas públicas (SUAIDEN, 1980, p.40).

No entanto, o INL (criado pelo DecretoLei n. 93, de 21-12-1937) somente concretiza a sua intenção em 1977 com a criação do Sistema Nacional de Bibliotecas Públicas (SNBP). O INL apresentou, naquele momento, como objetivos gerais para o SNBP os três seguintes:

"a. incentivar a implantação de serviços bibliotecários em todo o território nacional; b. promover a melhoria do funcionamento da atual rede de bibliotecas, para que atuem como centros de ação cultural e educação permanente; c. desenvolver atividades de treinamento e qualificação de pessoal para o funcionamento adequado das bibliotecas brasileiras" (SUAIDEN, 1980, p. 41).

Em maio de 1992, foi instituído no Brasil - Sistema Nacional de Bibliotecas Públicas (SNBP), desta vez regido pelo Decreto Presidencial n.520, com o intuito de fortalecer as bibliotecas públicas no País, “(...) de modo a favorecer a formação do hábito de leitura, estimulando a comunidade ao acompanhamento do desenvolvimento sócio-cultural do País."

Como princípio básico, o SNBP propõe construir "(...) uma sociedade verdadeiramente democrática e a formação de uma consciência crítica do indivíduo, levando-o ao exercício pleno da cidadania".

A maioria dos trabalhos que analisam o papel da biblioteca destaca seu caráter de difusor cultural, de democratizador do saber, afirmam eles que essa circulação de informação, por conter discursos contraditórios poderiam gerar pressões. A biblioteca, segundo essas análises, seria um agente transformador da sociedade (CARVALHO, 1991).

Se analisarmos, do ponto de vista de objetivos das bibliotecas públicas, ou melhor dizendo, do ponto de vista dos objetivos do Sistema Nacional de Bibliotecas Públicas, veremos que na verdade os verbos utilizados não são comprometedores: incentivar, promover, desenvolver, no primeiro momento; e com força de Decreto Presidencial, temos incentivar, promover, desenvolver, que nada mais são do que os objetivos já nomeados pelo INL. Ainda outros 
seis objetivos foram acrescentados, iniciados pelos verbos manter, incentivar (novamente), proporcionar, favorecer, assessorar, firmar. Em nenhum momento foi usado o verbo alocar, referindo-se a recursos financeiros. Entretanto, é preciso dizer, que o sexto objetivo diz respeito ao "repasse de recursos financeiros aos sistemas estaduais e municipais"; assim como deve "(...) fornecer material informativo e orientador de suas atividades".

Pela primeira vez, desde a criação da primeira biblioteca pública (1811), foi destinada verba para a manutenção desta instituição (1992). Agora, sim, pode-se falar em um início de políticas específicas para a biblioteca pública, pois anteriormente acreditava-se na colaboração exclusiva do cidadão.

Entretanto, no art. 6, Item I do Decreto Presidencial, há a menção das receitas destinadas ao Sistema Nacional de Bibliotecas Públicas, dirigido pelo Presidente da Fundação Biblioteca Nacional, para gerir os recursos financeiros "na forma de lei", mas nada mais é explicado. Fala-se também, no Item II, em “(...) celebrar convênios com instituições públicas ou privadas, nacionais ou internacionais, para a execução de seus programas;" e no Item III, "(...) firmar contratos de prestação de serviços, visando ao desenvolvimento de projetos a ele vinculados". Como aqui pode ser comprovado, o Decreto Presidencial (1992) é evasivo quando trata da questão do orçamento para as bibliotecas públicas.

Existe um programa promovido pelo Ministério da Cultura (RIZZO, 1998, p.32) denominado Uma biblioteca em cada município, que propõe convênios com os municípios. Neste programa, a parceria é distribuída da seguinte forma: a prefeitura destina um prédio e dois funcionários para a criação da biblioteca e a União envia a verba para a compra de 2 mil volumes, equipamentos, computador e, também, se responsabiliza pelo treinamento da equipe.
Em outros países, como Inglaterra e Estados Unidos, o surgimento de bibliotecas públicas, com o intuito de organizar e sistematizar os serviços aos usuários, deu-se durante o século XIX. "Tanto num caso quanto no outro, elas foram criadas com parte dos impostos recolhidos pelo governo" (CARVALHO, 1991, p.35).

Os serviços oferecidos aos usuários, nos dois países, tinham como propósito a educação do cidadão. Nos Estados Unidos, onde as bibliotecas sempre foram criadas e mantidas pela comunidade, o objetivo era prestar os serviços biblioteconômicos em igualdade de condições a todos os usuários. Na Inglaterra, a função era a de não perturbar a ordem, ou seja, estando na biblioteca, o povo "(...) teria acesso à boa leitura, fazendo das bibliotecas públicas o meio mais econômico de se manter homens exaustos e sem dinheiro entretidos em prazeres inocentes e portanto fora das prisões, tribunais e asilos" (CARVALHO, 1991, p. 35).

Bamberger (1977, p.17), convidado pela Unesco para escrever sobre a situação da leitura em todo o mundo, revela que a Inglaterra, não sendo a nação que compra mais livro per capita, é a que mais lê, pois o número de empréstimo por pessoa é o mais alto, isso porque o Sistema de Bibliotecas Públicas é o mais eficiente.

Da Escócia e Inglaterra, podemos destacar (VÁLIO, 1987) a atenção e a importância que se têm dado à formação de leitores, tanto com relação aos serviços oferecidos pelas bibliotecas públicas, como pelas bibliotecas escolares, nas escolas primárias e secundárias, assim como nas universidades, que prestam assessoria e desenvolvem projetos nas bibliotecas em geral. É preciso ressaltar o trabalho que é desenvolvido nos departamentos de serviços para as crianças, pertencentes ao Sistema de Bibliotecas Públicas, com relação à produção de material audio-visual para a educação de usuários; à produção de filmes, slides e vídeo-tapes para os programas educativos para a televisão. 
Outro país que tem investido no desenvolvimento de programas de bibliotecas públicas é Cuba (no qual participamos de uma Feria International del Libro, em 1987). Tendo como difusora a Biblioteca Nacional "José Martí", o Sistema Nacional de Bibliotecas Públicas atende 369 bibliotecas, sendo "(...) 13 provinciales, 155 municipales y 205 surcusales" (PENSADO, 1999). Se lembrarmos que Cuba tem uma população menor do que a cidade de São Paulo, podemos então avaliar o prestígio que tem as bibliotecas públicas.

Há no Brasil menos do que 500 livrarias e 4 mil bibliotecas (Pesquisa da Secretaria de Política Pública do Ministério da Cultura), dentre os vários tipos delas, o que corresponde a uma para cada 40 mil habitantes, sendo que "(...) nos Estados Unidos e Canadá, o índice é de uma para cada 10 mil habitantes" (RIZZO, 1998).

Em artigo de Pensado (1999), apresentado na 60th IFLA General Conference, pode-se notar o trabalho que é dedicado às crianças e jovens cubanos. Na publicação, o autor enfoca "(...) el desarrolo y estado actual de las bibliotecas públicas para niños".

Diz Pensado (1999):

El servicio para niños está contemplado en todas las bibliotecas del sistema de bibliotecas públicas incluendo las de montaña y las creadas en los bateyes de los centrales azucareros. Tambiém los bibliobuses tienen un gran número de entusiastas e fieles lectores entre los niños. Todas las bibliotecas para niños son secciones o departamentos de bibliotecas públicas y dependem de una dirección, administración $y$ departamentos de servicios $y$ procesos técnicos únicos.

O autor complementa, dizendo que:

Los fondos son por su contenido universales y los servicios se estructuran en correspondencia con las edades y intereses de los usuarios. La generalidad de las bibliotecas poseen dos áreas o salas o en su lugar una sala dividida convenientemente en dos área con el fin de estabelecer el servicio diferenciado a niños y adolescentes. Esto permite crear dos ambientes diferentes $y$ agradables para las distintas categorías de usuarios que a ellas asisten.

Pensado discute no artigo os serviços que são dedicados às crianças e aos jovens pelas bibliotecas públicas.

Na Irlanda, outro país que também possui um Sistema de Bibliotecas Públicas exemplar e que tem uma política bem definida para o seu funcionamento, o Ministro Dempsey (IRELAND, 1998) publicou um relatório, em 26/11/1998, “(...) contendo as estratégias para o desenvolvimento do serviço" do Sistema de Bibliotecas Públicas irlandês, ou seja:

- enhance access to information using information and communications technology (ICT); • enhance access to lifelong education through library collections and services; • new avenues for social inclusion based upon the provision of information-based skills-training; - enhanced access to library collections of high cultural value; - enhanced delivery of government services using ICT infrastructure in the library.

O Ministro dobrou a verba para as bibliotecas públicas, que era em 1998 de 3,2 milhões para 6,6 milhões de libras. Isto demonstra uma verdadeira preocupação com a educação do povo e, principalmente, com relação ao acesso à informação e ao exercício de cidadania.

No artigo de Briggs (1999), fruto de uma pesquisa qualitativa, realizada para estudar o 
valor econômico e social de uma biblioteca pública australiana - a Lane Cove for the State Library NSW, é mostrada a importância dessa instituição ao afirmar que

All time spent getting information at the library can be classified as either production or consumption, where the former represents work at the marketplace in return for income, and the latter is essentially leisure-related. Income is therefore forgone if productive time is used for leisure-related library use.

Com essa afirmação, é possível entender realmente a função da biblioteca pública: ser uma instituição da comunidade que dá acesso ao conhecimento, à formação do cidadão para o desempenho de suas potencialidades de produção e, ao mesmo tempo, oportunizar ao seu usuário momentos de lazer e descanso para poder usufruir dos bens sócio-culturais. São justamente esses bens culturais que podem providenciar a formação do usuário/leitor como cidadão de uma dada comunidade.

Diante deste cenário apresentado, foi proposto este Projeto de Pesquisa.

\section{A TERIALE MÉTODOS}

A pesquisa foi realizada em etapas, de modo que foi descrito o método correspondente a cada uma delas.

Etapa 1 - Identificação das zonas da cidade quanto ao atendimento pelas bibliotecas.

- Material: Esta parte consistiu em uma pesquisa documental feita a partir do fichário do usuário cadastrado nas quatro bibliotecas de Campinas, no qual é localizável o endereço da pessoa. Desse modo, foi utilizado o registro da população de usuários cadastrados no primeiro semestre de 2002, o qual antecedeu a coleta de dados.
- Procedimento: De acordo com o registro na ficha do usuário, foi feito o lançamento no rol das zonas da cidade. Completado o rol, os dados foram analisados. Para garantir fidedignidade e facilidade de registro no rol, a tarefa foi feita por dois bolsistas trabalhando concomitantemente.

Etapa 2 - Levantamento de Interesses de Leitura - foi aplicado um Roteiro de Entrevista Estruturada (Anexo 1), que foi reelaborado por duas vezes (após dois Pré-testes), para diagnosticar os interesses de leitura de pessoas de várias faixas etárias, e níveis educacional e profissional diferentes.

Os Resultados e Discussão das Etapas 1 e 2 estão descritos em trabalho já publicado (VÁLIO et al., 2003).

Etapa 3 - Teste de Eficiência de um Programa de Atendimento - momento da implantação dos Ônibus-Biblioteca Itinerantes, o Programa teve a duração de um período de quatro meses.

\section{PROCEDIMENTOS METODOLÓGICOS DA ETAPA 3}

A partir dos resultados e conclusões levantadas nas Etapas 1 e 2 a Etapa 3 da Pesquisa - Teste de Eficiência de um Programa de Atendimento, foi desenvolvida.

De acordo com os objetivos da Etapa 3 e as conclusões definidas na Etapa 2, elaborou-se um Roteiro de Observação (Anexo 2), com a finalidade de conhecer-se as necessidades dos usuários e das usuárias, ou seja, o uso que farão dos acervos e a participação deles nas atividades de leitura implantadas.

Com esta última etapa cumprida, é possível apresentar à instituição parceira os modos de ação provenientes da Pesquisa, para que se estabeleçam as Políticas Públicas com relação à oportunidade dos moradores de bairros periféricos poderem ter acesso às Bibliotecas Públicas, com vistas à educação continuada e, 
portanto, poderem ter direito ao exercício de sua cidadania.

Para sugerir à Instituição Parceira, a Prefeitura Municipal de Campinas, um Projeto de Políticas Públicas, com respeito à rede de Bibliotecas Públicas, um último aspecto foi analisado, a partir dos dados colhidos durante as entrevistas realizadas na Etapa 2. Este aspecto é aquele referente ao conceito, à tipologia e ao conhecimento do que se entende por Biblioteca, na visão dos respondentes dos questionários, moradores dos 40 bairros selecionados.

\section{Bibliotecas: freqüência, tipo, interesse e local}

$\mathrm{Na}$ apresentação dos Resultados e Discussão dos dados, a análise esclarece como o futuro usuário entende a Biblioteca.

Pelas respostas à questão 5 (Anexo 1), é demonstrado que quase $70 \%$ dos sujeitos não só conhecem como já visitaram uma biblioteca. Em vista disso, aduz-se que uma pequena maioria (30\%) nunca esteve nesta instituição.

Embora quase um terço dos sujeitos dissessem que nunca foram a uma biblioteca, $88 \%$, dos quais a conhecem, souberam indicar os dois tipos de bibliotecas: escolar e pública, existentes nesta cidade. Esses dois tipos de bibliotecas são, na verdade, considerados os mais populares, pois os outros dois, especializadas e universitárias, são: as primeiras freqüentadas pela elite de empresas ou centros de pesquisas; as outras, fazem parte da elite acadêmica.

As respostas dizem que os moradores dos 40 bairros vão mais à Biblioteca Pública (58\%), enquanto que menos do que a metade já visitou uma Biblioteca Escolar. Outros tipos de biblioteca poucos conhecem (9,7\%).

No entanto, os entrevistados confirmam a ida a uma Biblioteca, se considerarmos que mais da metade da população amostrada fez empréstimo de livros ou da Escolar ou da Pública. Desse modo, se $55,1 \%$ dos sujeitos emprestam livros da biblioteca, isto indica que freqüentarão os dois ônibus do nosso Projeto Leitura em Movimento.

Mais ainda se comprova o conhecimento dessa instituição pelos entrevistados, quando perguntamos: "5.4-Qual a última vez que você foi a uma Biblioteca?" A metade dos respondentes (50,2\%) afirmou que não freqüenta uma biblioteca há mais de um ano. Entretanto, 22,1\% são assíduos usuários de biblioteca, enquanto que $31,9 \%$ demonstraram ter ido a essa instituição mais espaçadamente (de 7 meses a 1 ano).

Quanto aos interesses encontrados na biblioteca pública, 24,8\% dos entrevistados não sabem o que lá existe, enquanto outros citaram diferentes tipos de obras que constituem um acervo. Quer isto nos mostrar que há respondentes que possuem um conceito sobre biblioteca, com respeito ao acervo e, principalmente, dizendo que ela possui livros $(39,1 \%)$, e não se esqueceram de citar as obras de referência como Bíblia, Biografia, Dicionários. Lembraram-se também de falar que na biblioteca faz-se Pesquisa, juntando, assim, o conceito de biblioteca como coleção de livros e o de que é ela o local da Pesquisa, pois, existem lá as obras de referência para serem consultadas na realização de trabalhos escolares.

A opinião dos participantes sobre a biblioteca foi positiva, pois o percentual de $83,8 \%$ obrigou-nos a refletir que eles valorizam a biblioteca e, portanto, cabe-nos a responsabilidade de manter neles essa mesma expectativa com relação aos ônibus-biblioteca.

Nas respostas dadas, houve um alto percentual $(76,59 \%)$ de freqüência às bibliotecas existentes nos bairros, sendo que, de 880 sujeitos, 35,11\% vão a essa instituição para realizar "Pesquisa Escolar". Este dado faz-nos concluir que os usuários da biblioteca, neste 
caso, são estudantes e as bibliotecas existentes são as escolares. É promissor, por um lado, acreditar que $46,59 \%$ têm uma visão positiva da biblioteca, mas, por outro, há $11,36 \%$ que a vêem de um modo negativo.

Percebemos, outrossim, que esta população dos bairros amostrados são cidadãos vulneráveis à "desfiliação" (CASTEL, 1997), ou seja, são eles os excluídos de contextos sócio-culturais, o que, acreditamos, a Leitura em movimento tem procurado providenciar.

Para selecionar os locais de estacionamento dos ônibus, foram coletadas as sugestões dos moradores de cada bairro, durante o momento das entrevistas. Assim, os entrevistados responderam à questão 5.10 - Em que local ela (a biblioteca) deveria ficar para ser de fácil acesso para todos do bairro? A opinião dos moradores de cada um dos 40 bairros foi considerada e analisada para a determinação do estacionamento dos ônibus-biblioteca. A indicação destes locais pode ser, futuramente, onde as bibliotecas setoriais serão construídas.

Os acervos qualificados, de acordo com as conclusões da investigação realizada na Etapa 2 - Levantamento de Interesses de Leitura, após a seleção e aquisição dos acervos e decisão do estacionamento, os dois ônibus-biblioteca, com o nome de Leitura em movimento, começaram a circular pelos 40 bairros selecionados.

Em seguida, com o objetivo de conhecer o comportamento das pessoas, que freqüentam os ônibus e o uso que elas fazem do acervo, iniciamos a coleta de dados, cujo instrumento de pesquisa foi o Roteiro de Observação (Anexo 2).

Para a análise dos dados, elaboramos os quadros do Roteiro de Observação por bairros e, em cada bairro, discriminamos as observações em sete colunas.

$\mathrm{Na}$ coluna Sujeitos, foi anotada a descrição daqueles observados, ou seja, identificação numeral deles, S1, S2...e seguintes, e faixa etária de cada um.
Com referência ao item 1. comportamento dos sujeitos, as três colunas seguintes descrevem o modo como foi: a) chegada; b) acesso ao acervo e c) ação. O item 2 foi designado como Tipo de acervo escolhido; o 3으, Satisfação ou não e o $4^{\circ}$ e último refere-se às Observações.

A faixa etária dos sujeitos observados foi distribuída em 4 categorias: criança, adolescente, adulto e idoso. As outras categorias foram indicadas pela combinação das quatro classificações, ou seja: criança acompanhada por adulto; criança acompanhada por dois adultos; dois adolescentes; dois adultos; e assim por diante.

Podemos ressaltar que pessoas vão aos ônibus também em grupos, sejam adultos, adolescentes ou crianças. Estas, se são menores de 12 anos, precisam estar acompanhadas dos pais ou responsável para poderem cadastrarse. Parece ser costume também os pais escolherem o material de leitura para os filhos.

O comportamento dos freqüentadores dos ônibus foi observado nos três aspectos: a) chegada; b) acesso ao acervo e c) ação.

Quanto à chegada dos(as) usuários(as), eles(as) apresentaram os seguintes comportamentos:

- desejam conhecer o ônibus;

- cadastrar-se;

- pedem informações sobre o ônibus, ou seja: "o que é e como funciona o ônibus biblioteca", "é pra vender" livros, "é pra dar" livros, "aceita doação" e perguntam também "o que precisa fazer pra tirar livro";

- perguntam, quando o ônibus chega; se já podem subir, pois estavam esperando no local;

- perguntam o que acontece quando não devolvem o livro;

- dirigem-se às estantes ou a um dos acervos;

- devolvem os livros que a pessoa emprestou e/ou também aqueles emprestados pelos 
filhos, pelos pais, pelos irmãos, pelos amigos, pelos vizinhos. Este é o comportamento mais freqüente;

- devolvem os livros retirados com atraso e são avisados que, por isso, não podem levar outro dessa vez;

- renovam o empréstimo do livro que ainda não leram ou quando alguém da família também quer ler e não teve tempo;

- entram pela primeira vez no ônibus e perguntam se é preciso pagar;

- cumprimentam as pessoas dentro do ônibus e dirigem-se aos acervos;

- pedem auxílio para a bibliotecária;

- olham, procuram nas estantes e não escolhem;

- pegam um livro da caixa de devolução;

- ficam lendo jornal nas mesinhas fora do ônibus;

- vem encontrar um colega e resolve buscar os documentos para cadastrar;

- chegam com a professora;

- a professora vem devolver os livros retirados pela sua classe.

Pela análise das observações, concluimos que o acervo mais procurado é o de Literatura Infantil tanto pelos pais, irmãos ou pelas crianças. São procurados, dentro do acervo de Literatura Infantil, os Contos de Fadas. As crianças menores gostam dos livros brinquedos. Os autores conhecidos pelas crianças, pelos adolescentes e por elas/eles nomeados são Monteiro Lobato, Ana Maria Machado, Pedro Bandeira, João Carlos Marinho, Ziraldo. As crianças também gostam de pegar livros ou revistas de atividades (ligar os pontos, descobrir objetos, figuras ou animais em um desenho), folheiam, ou vão sentar-se para resolver as questões.

Com respeito à Literatura Infanto-Juvenil e Juvenil, há uma busca pelas Coleções Veredas,
Vaga-Lume, Para Gostar de Ler, Coleção Castor, sendo a segunda delas a mais solicitada. Os livros mais retirados são aqueles do "Harry Potter".

$\mathrm{Na}$ Literatura Universal, os autores de romances nomeados pelos usuários(as) são Conan Doyle, Shakespeare, Sidney Sheldon, Na Literatura Inglesa, há solicitação de Romances Policiais de Agatha Christie. Os(as) usuários(as) sabem o que querem, quando pedem por um específico autor.

Dois dos livros mais solicitados são: Carandiru de Dráuzio Varela, cujos três exemplares nem sempre estão disponíveis; e Pavilhão 9, de Hosmany Ramos.

Entre os autores brasileiros, são lembrados: José de Alencar, Machado de Assis, Malba Tahan, Dráuzio Varela, Dalton Trevisan, Adelaide Carraro, Mário Donato, João Ubaldo Ribeiro, Paulo Coelho, Autran Dourado.

Quanto ao acesso ao acervo de Informativos, os(as) mais procurados pelos leitores(as) estão listados a seguir:

- Culinária - é o acervo mais visitado;

- Saúde - principalmente a Coleção Saúde e Sabor, e Doenças;

- Ecologia/meio ambiente;

- Artesanato - moldes, bordados, crochê e fitas, costura;

- Esporte - livros sobre a História dos times, jornais e revistas: Placar, Lance, de motos;

- Viagem - Guia Quatro Rodas;

- Auto-ajuda;

- Religião - Catolicismo, Espiritismo, livros evangélicos;

- Crenças - Signos, Astrologia;

- Revistas sobre cães e gatos, revistas sobre música, rock, folclore, mágicas e aquelas famosas: Caras, Isto É, Cláudia; 
- Biografias de pessoas famosas é também um dos acervos mais visitados.

- Pedem livros sobre Reeducação Alimentar, Educação Sexual, Enfermagem, Psicologia, Astronomia.

O assunto, Biografias de pessoas famosas, por exemplo, seria um acervo que não compraríamos se não tivéssemos feito a pesquisa sobre interesses de leitura dos(as) leitores(as) dos 40 bairros. O mais importante é que temos acervos para atender a todos.

Há solicitação de livros para o vestibular (embora em número pequeno). Perguntam por livros de História Geral e História do Brasil, por regime político, por Química, Ciências.

As revistas são muito folheadas, retiradas do expositor, sendo Caras, Isto É as mais escolhidas. O gibis também são muito visitados e lidos dentro do próprio ônibus ou nas mesinhas que ficam embaixo do toldo, do lado de fora.

Nos dados sobre o acesso ao acervo, referentes aos ônibus 1 e 2, encontramos observações interessantes, que são elencadas abaixo:

- namorado da usuária é cozinheiro em um hotel. Em vista disso, ela selecionou um livro de Culinária para ele;

- como a criança não teve tempo para escolher, porque a mãe estava com pressa, retirou qualquer livro infantil;

- uma criança pede orientação sobre a organização dos livros nas estantes;

- uma usuária adulta solicita um livro sobre beleza feminina;

- pai diz aos dois filhos que gibi não presta; chega a mãe e ajuda a escolher.

Há dois(duas) usuários(as) que são deficientes físicos. Infelizmente estes dois usuários não podem visitar o ônibus e nem selecionar livros de sua escolha. São, portanto, ajudados pelas bibliotecárias.
O que nos chama a atenção, entretanto, é que os acervos selecionados e adquiridos para os dois ônibus, a partir de critérios rigorosos estabelecidos pela equipe do Projeto, estão de acordo com as necessidades e interesses dos nossos(as) leitores(as).

O último item sobre o comportamento do(a) usuário(a) é a ação. O objetivo do item ação é conhecer como o(a) usuário(a) seleciona e retira o livro que pretende ler.

- Há pessoas ou crianças (acompanhadas de adulto/a), que por estarem com pressa, retiram qualquer livro. Na verdade, mesmo com pressa, é importante levar um livro ou outro material para ler. Assim parecem pensar os nossos(as) usuários(as).

- Dirigem-se a uma determinada estante e retiram um livro sem olhar as outras. Esses(as) leitores(as) sabem exatamente o que querem, vão direto à estante onde está o material de leitura preferido.

- Circulam pelo ônibus e procuram em todas as estantes.

- Solicitam ajuda da bibliotecária, ou da mãe, ou do pai, ou da filha, ou de um adulto(a), ou de irmão(ã), ou de amigo(a), para escolher o material de leitura desejado. São estas pessoas que precisam de ajuda para decidirem. Uma adulta deixou que o sobrinho escolhesse um livro para ela do acervo de Literatura Infantil.

- Às vezes, quando solicitam ajuda da bibliotecária, ela recomenda o mesmo ou um outro autor ou outro material de leitura. A bibliotecária recomendou a uma senhora o autor Garcia Roza e ela retirou um livro dele.

- Outros escolhem material de leitura sem solicitar ajuda.

- Por ter problemas mentais, a criança teve necessidade da ajuda da bibliotecária. Sendo ajudado, escolheu um livro infantil de seu interesse. 
- Retiram o livro que reservaram da vez anterior.

- Vão com a carteirinha de outros leitores e retiram 2, 3, 4, 5 livros.

- Retiram livros para si e para toda a família.

- Uma criança escolhe rapidamente livros para si e espera a avó selecionar o dela. Outra, depois de selecionar o seu livro, vai até o acervo de informativos escolher um para a avó (folclore).

- Dois adultos retiram livros e dizem que devolverão no bairro vizinho, após três dias, para poderem retirar mais.

- Visitam diferentes acervos, até se decidirem por um específico material para ler. Por exemplo: procuram no acervo de Poesia, no acervo de Literatura Infantil, lêem gibis. Às vezes, elas decidem por outro material de leitura.

- Folheiam/lêem diferentes materiais do acervo para retirar aquele que melhor thes agrade. Selecionam livros, revistas e sentam-se para folhear e/ou ler. Retiram, com segurança, o que querem ler, porque encontram o material de leitura desejado.

- Uma criança revela o seu critério para escolher livro: "só gosto de pegar livros de capa dura".

- Há uma outra criança, que tem exigentes critérios de escolha: pega livros de poesias, senta-se no ônibus e lê alguns trechos de alguns livros, escolhendo qual emprestaria; conversa sobre livros que já conhecia; pergunta quantos livros poderiam ser emprestados, escolhe um livro e dirige-se à bibliotecária. Depois, pega material informativo da prefeitura e começa a lê-lo no interior do ônibus; troca-o por um gibi, que depois devolve ao acervo para ir procurar livros infantis para sua irmã mais nova que já havia saído do ônibus.

- Mais uma criança demonstra o seu interesse pela leitura: enquanto segurava o primeiro livro que havia pego, passa a folhear outro livro que logo foi devolvido ao acervo. Pede para sua mãe segurar o primeiro livro e desce do ônibus para ir buscar os documentos da mãe para que ela se cadastrasse no projeto. Volta com os documentos e passa a procurar um livro de Literatura Infanto-Juvenil para seu irmão que já está cadastrado como usuário, mas que não pudera vir até o ônibus neste dia. Pergunta à bibliotecária se poderia renovar o empréstimo e decide-se por um livro "grande". Esperou enquanto sua mãe se cadastrava e depois entregou os livros que havia escolhido para que fossem feitos os procedimentos necessários para o empréstimo.

Outros exemplos do modo como a criança escolhe a sua leitura:

- desce do ônibus, volta, pega um livro de capoeira e diz que quer aprender; pega, na estante de Literatura Juvenil, "Harry Potter", mas reclama por não ter desenho; retira alguns gibis e senta-se para ler "Assim Assado"; lê alto um trecho que achou "legal" para um colega que não sabe ler; lê um livro em voz alta, acompanhando com o dedo.

Podemos exemplificar, agora, como uma adolescente faz a sua escolha:

- "apresenta" o ônibus a sua amiga que o visita pela primeira vez. As duas passam a procurar por livros infanto-juvenis, sem retirá-los das prateleiras. Começam a conversar sobre quanto tempo levariam para terminar a leitura de cada livro. Escolhem cada uma o que levar (a observada retira um livro e sua amiga uma revista, em nome da mãe da usuária já cadastrada) e entregam à bibliotecária para os procedimentos necessários.

Aqui está um adulto selecionando a sua leitura:

- procura por livros de literatura adulta, olha, por pouco tempo, o acervo de literatura infanto-juvenil e volta a procurar por livros de literatura adulta. Pega um livro e depois vai 
conversar com um colega sobre livros de xadrez. Acaba optando por um livro de xadrez.

- Adolescentes ficam lendo livros e/ou revistas nas mesinhas, dentro ou fora do ônibus.

- Marido vem retirar livros ou revistas para a esposa.

- Leu sobre o ônibus no jornal da Transurc (entidade dos empresários de ônibus, que nos doou os dois ônibus) e veio conhecê-lo. Gostou muito.

- A maioria dos(as) freqüentadores(as) visitam o acervo de Literatura Infantil porque é lá que as crianças selecionam os livros para si ou porque os pais escolhem por elas.

- Olham as capas e contra capas ou lêem os resumos dos livros para poderem escolher aquele que desejam.

- Quer livro grosso para ler nas férias de janeiro. Há pessoas que optam pelo número de páginas do livro.

- Outra quer levar vários livros porque tem muito tempo de férias.

- A criança opta por um livro brinquedo, mas o pai aconselha-a a retirar um livro com texto. Nem sempre é a própria criança a selecionar o que deseja para "ler".

- Há pessoas que selecionam livros em uma determinada estante, mas, por fim, escolhem o que ler em outro acervo. Um leitor, por exemplo, gostou do livro sobre karatê, mas, como pratica capoeira, preferiu levar um que conta a história e mostra como fazer os exercícios deste esporte.

- Escolhem livro da caixa de devolução.

- Gostam dos livros de série (Veredas, Vaga-lume, Para gostar de ler) e indicam aos amigos.

- Uma criança solicita mais um livro da Coleção Castor.

- Dois adultos retiram dois livros para trocarem entre todos da casa. Esta é uma atitude freqüente entre os(as) usuários(as) do ônibus. Acham que 15 dias é muito tempo para esperar o ônibus voltar.

Percebem que esta espera é muito longa, pois essas pessoas têm necessidade de serem leitoras, conhecer, saber mais. Com esses exemplos, notamos que os leitores descobriram que a biblioteca tornou-se importante para as suas vidas. Esta postura mostra o quanto a biblioteca pode contribuir socialmente para que essas pessoas se realizem como leitoras (BRIGGS,1999).

- Pai prefere levar um livro para ler para o filho de quatro anos.

- Retiram material de leitura para outra pessoa, fundamentando-se nas preferências citadas por aquela.

- A mãe lê os títulos dos livros para a criança e esta ri.

- Solicita livros sobre uma determinada religião.

- Trouxe uma lista de assuntos para procurar. Quer livro sobre a organização social e política de Campinas.

- Escolhe um livro sobre extraterrestres.

- Procuram conhecer todo o acervo do ônibus. Uma criança analisa o ônibus comparando-o com um ônibus de passageiros.

- Adulto não quer mais ler romances. Vai ler novamente $O$ pequeno príncipe.

- Quer Estação Carandiru que está emprestado. Folheia alguns livros de poesias.

- Veio devolver Estação Carandiru, mas já trouxe junto uma pessoa para retirá-lo.

- Um adulto solicitou Senhor dos Anéis, folheia e faz a retirada. Outro procura por Grande Sertão: Veredas. Outra pessoa quer material de leitura sobre filme. Mais uma folheia livros e procura por um "que tenha temperos". Uma adulta decidiu-se por um livro de José de Alencar porque no título está o seu nome Encarnação. 
- Retiram revistas ou livros e ficam lendo em pé.

- Ficam lendo livros de Psicologia que tratam da educação dos filhos.

- Lêem alto para as pessoas: o jornal, sobre futebol.

- Retira livro de Literatura Russa, mas quer livros com ilustrações porque só com palavras cansa ler.

Se só "com palavras cansa ler", é porque o texto escolhido não atende ao nível e ao ritmo de leitura desse leitor. Com a prática, lendo novos títulos, o leitor poderá desenvolver e mudar para outro nível e ritmo de leitura, cumprindo a sua própria história de leitor (VÁLIO, 1996). Como esses usuários não tiveram, até então, oportunidades de acesso a uma disponibilidade de textos escritos, eles foram participantes da exclusão pela leitura (BARBOSA, 1999).

- Muitos(as) usuários(as) não retiram porque vão estar em férias e vão viajar.

- Há pessoas que solicitam um determinado título e quando são informadas que o livro está emprestado, vão embora sem retirar outro livro.

- Selecionou três livros. Para escolher um deles, folheou novamente os três.

- Retira um livro que, segundo ela, possui informações sobre mulheres que trabalham.

- Foi várias vezes às estantes, retirou livros e sentou-se para lê-los. Repetiu esta ação por aproximadamente uma hora.

- No dia em que as pessoas se cadastram, demonstram satisfação por poder começar a ler. Quando isto aconteceu com um senhor, ele fez perguntas e ligou para o filho vir conhecer o ônibus-biblioteca e retirar livros.

- Lêem o jornal e, em seguida, vão embora. Vêm exclusivamente para ler o jornal.

Respeitar o interesse, o nível e o ritmo de leitura de um(a) leitor(a) é essencial para que ele(a) desenvolva a sua própria história de leitura. Adultos lêem livros infantis, os contos de fadas por exemplo e, depois, podem procurar outros tipos de leitura. Crianças, com mais oportunidades de leitura, podem ler livros que consideramos para adultos. Concluindo, queremos dizer que são as oportunidades, geradoras das práticas de leitura, que possibilitam os diferentes interesses, níveis ou o ritmo de leitura, ou seja, uma história de leitura (VÁLIO, 1996).

Até o término da aplicação do Roteiro de Observação (19 de dezembro de 2003), todas as solicitações puderam ser atendidas, com exceção, naturalmente, quando pediam um título que se encontrava nas mãos de outro(a) usuário(a).Quanto ao comportamento: c) ação, foram selecionados dos comentários coletados os registrados abaixo:

- As pessoas chegam com a intenção de retirar um específico livro, mas começam a folhear livros e revistas nas estantes ou no expositor e decidem-se por outro tipo de leitura. Como por exemplo: anda pelo ônibus. Folheia alguns livros de poesia e retira um de Humor; fica no acervo sobre música e pergunta se não há mais livros sobre esse assunto (opta por Crônicas Brasileiras); folheia alguns livros, lê resumos da Coleção Veredas e pede livros de piadas (retira livro de Humor).

- Crianças e adolescentes ficam no ônibus lendo gibis, revistas de esportes (futebol, Jiu-Jitsu, Judô), Caras, Isto É.

- É indicado a uma adolescente o acervo de Literatura Juvenil, mas ela não olha. Permanece no acervo de Literatura Infantil e dele retira o livro que quer ler.

Esta leitora está desenvolvendo a sua história de leitora, obedecendo seu nível, ritmo e interesses de leitura. Assim, com a oportunidade de ler, poderá não ser uma adulta com escolaridade tardia, como disse Castro (1999). 
- Não retira mais livros porque não tem tempo para ler.

- Doam revistas para o ônibus.

- Não podem retirar a revista do mês corrente.

Os gêneros em prosa preferidos pelos leitores são Romance, Crônica, Contos de Terror (apenas um sujeito), Humor. Poesia foi escolhida por 30 sujeitos, cujos títulos estão distribuídos pelas Literaturas Brasileira, Norte-Americana e Inglesa.

A divisão da Literatura, para crianças e jovens, em Infantil, Infanto-Juvenil e Juvenil é apenas uma questão do modo como os dados foram coletados, pois, como não haviam sido estipuladas as categorias literárias, estas foram registradas espontaneamente, não havendo, portanto, diferenças entre uma e outra (HUCK, 1999). Isto significa dizer que os jovens e crianças perfizeram um total de 311 materiais de leitura retirados com respeito ao item 2 . Tipo de acervo escolhido.

A categoria de Literatura Norte Americana e a de Literatura Inglesa referem-se respectivamente ao gênero de Romances: Norte Americanos e Ingleses.

O estacionamento do ônibus é perto de uma escola. Como alunos e professores estavam em férias, houve um prejuízo na retirada dos livros. Entendemos, portanto, que as pessoas do bairro consideram o ônibus exclusivo dos alunos da escola e não para os moradores do local. Este mal entendido precisa ser esclarecido, pois o Projeto Leitura em movimento tem como objetivo precípuo atender a todos os cidadãos de todas as idades e não somente os estudantes, pois dois ônibus com os respectivos acervos fazem parte da Rede de Bibliotecas Públicas de Campinas. Portanto, não é Biblioteca Escolar, mas biblioteca para uso dos cidadãos exercer sua cidadania.

De acordo com os resultados acima, o cidadão entende que o ônibus-biblioteca é somente para aqueles que participam do momento de ser escolar, os que não freqüentam mais a escola estão excluídos da oportunidade de ler (RIBEIRO, 2002).

Quanto ao tipo de acervo escolhido pelos usuários, foi objetivo deste item também conhecer e analisar os assuntos informativos, escolhidos pelos sujeitos.

É importante registrar que a ida ao ônibus, muitas das vezes (como podemos aduzir dos dados coletados e registrados no Roteiro de Observação do Ônibus 1), levava o sujeito a ir acompanhado, ou seja, por um amigo, pelo pai ou pela mãe ou por uma pessoa adulta. É marcante também a vinda de famílias inteiras: filhos, pai, mãe, avós, irmãos.

Conhecendo o tipo de acervo preferido pelos(as) leitores(as), a observação seguinte refere-se à satisfação ou não pela leitura realizada. Faz-se necessário explicitar que se trata de uma observação do comportamento, das atitudes apresentadas pelos sujeitos amostrados, portanto, nenhuma pergunta de quem estava observando foi feita. Os dados aqui revelados estão vinculados somente na observação e nas palavras espontâneas do que foi dito pelos(as) usuários(as) dos acervos.

Embora os observadores não tenham feito nenhuma pergunta, mais da metade dos leitores(as) $(53,4 \%)$ manifestou espontaneamente a sua satisfação em ler, pois eles se transformaram em leitores, são, os incluídos (BARBOSA, 1999) e não mais os "desfiliados" pela leitura (CASTEL, 1997).

A satisfação das pessoas, freqüentadoras dos ônibus, pode ser demonstrada nos exemplos selecionados:

- Gostou, mas o livro é triste.

- Gostou, mas não acabou de ler.

- A mãe está satisfeita com o livro que retirou. Mas a criança ficou insatisfeita, pois o livro que a mãe escolheu "era muito grosso e chato". 
- Disse que correu da última vez que o ônibus esteve no bairro, mas não conseguiu alcançá-lo.

- É a primeira vez que entra em uma biblioteca. Achou muito bom.

- Feliz e ansioso para pegar mais material de leitura.

O último item: Observações, tem como objetivo conhecer melhor os(as) nossos(as) leitores(as), a partir do que não foi previsto nos itens anteriores. É, portanto, uma observação aberta, na qual são registradas as especificidades observadas.

Assim, podemos destacar, a seguir, as observações realizadas e as referentes categorias, durante a permanência dos(as) usuários(as) dentro do ônibus.

\section{Renovação de livros}

- Renova o livro antes retirado e, por estar com pressa, sai rapidamente do ônibus.

- Renova a retirada do livro porque não conseguiu terminar de lê-lo.

- Não terminou de ler o livro por falta de tempo. Gostou muito quando soube que poderia renovar.

- Quer renovar "porque teve uns contratempos e, como não é poesia, que nem que não lê tudo não tem problema".

\section{Desejo de ler}

- A criança, feliz, mostra a todos o livro que escolheu. Outra também está muito feliz porque encontrou o livro que queria ler. Uma outra fica eufórica para pegar o livro na mão.

- Permanecem dentro do ônibus lendo, durante o tempo todo em que ficamos no bairro.

- Já aguardava a chegada do ônibus.

Há um desejo de ler tão grande, que muitos ficam esperando ansiosos o ônibus chegar, com os livros embaixo do braço, para poderem retirar outro.

- Um adolescente gostou do livro que leu. Como em sua casa estava sem luz, foi ler no bar. Cansou de ler Literatura porque "acaba com a gente".

Aqui também se revela um desejo tão grande de ler que o leitor descobre meios para poder realizar a sua leitura.

- Leu o livro As vinhas da ira em dois dias. Quer trocar os livros em outro bairro para poder pegar mais. Uma senhora mora em outro bairro e vem até este "para entregar o livro e pegar outro. Reclama que o ônibus demora para voltar e que só pode pegar um livro".

- Diz que vai ler também o livro que escolheu para a esposa.

- Fez cadastro para o marido e disse que irá ler o livro dele também.

- Fala que gostaria de "poder ficar mais no ônibus".

- Fica um bom tempo no ônibus lendo, apesar das "gozações" dos amigos.

- Fica lendo no ônibus, enquanto seus familiares escolhem os livros.

- Adulto conta que na Biblioteca Pública as pessoas esperam até três meses por um livro.

- O ônibus estava lotado, uma senhora nem percebeu, mas, mesmo assim, permaneceu em pé lendo revista.

- Criança comenta que era o livro que mais queria levar: Franjinha.

- Apesar da chuva e do barro e ser uma pessoa idosa, veio devolver o livro e retirar outro. Uma outra senhora idosa analfabeta retira livros de culinária para o filho, desde a primeira vinda do ônibus. Por isso, solicita ajuda da bibliotecária.

Esta senhora faz parte daqueles marcados pela "exclusão" da leitura (BARBOSA, 1999), dentro dos "processos de marginalização" 
(CASTEL, 1997), não podendo ter acesso à biblioteca, a qual preserva a cultura dominante (CARVALHO, 1991). É bem possível, que ela leve o livro de Culinária para o filho ler para ela.

- Dois adultos sugerem que fôssemos a todos os bairros. Disseram que acordaram cedo, limparam tudo para depois ficarem "por conta dos livros".

- Vão embora folheando o livro.

- Normalmente ele passa mais tempo dentro do ônibus. Fica lendo. É um leitor.

- Disse: "quando vi os livros de religião fiquei com vontade de ler todos".

- Por não ter conseguido alcançar o ônibus da última vez, lamentou-se porque já podia ter lido os livros.

- É participante assíduo do ônibus.

- Trabalha à noite e gosta de ler.

- É usuária do ônibus biblioteca desde o primeiro dia que ele foi ao bairro. Já leu toda a coleção Sabor e Saúde que fala sobre ervas medicinais. Uma outra pessoa também é usuária desde a primeira vez da visita ao ônibus e, outro dia, ela disse "estar contente com a vinda do ônibus", pois voltou a ler, "devido a facilidade de se retirar um livro".

- Duas crianças ficam juntas "lendo" (ainda não são alfabetizadas) um livro.

- Participante adulta, desde a primeira vez que fomos ao bairro, retira sempre livros de Literatura Infanto-Juvenil para si.

- Primeira vez que entra na biblioteca. Solicita, por isso, sugestão de leituras mais fáceis para poder começar a ler.

As duas últimas usuárias são alfabetizadas, mas estão em nível de letramento, pois revelam uma "Leitura de escolaridade tardia" (CASTRO, 1999).

\section{Pais selecionam os livros para os filhos}

- A mãe não deixa o filho retirar o livro que ele deseja.
- A mãe seleciona dois livros para si e não permite que a criança leve nenhum.

Nessas falas podemos observar dois exemplos de atitudes que precisam ser discutidas com os pais, alertando-os sobre a importância da leitura para a criança e da escolha ser feita por ela mesma.

- A mãe quer indicação de livros para ensinar as crianças.

- Mãe veio para pegar livros para os filhos e leva também um livro para si.

- Pai propõe-se a ler para o filho e não só deixá-lo com o livro. Ajudou a achar um livro para o filho.

- Mãe deixa a filha no ônibus e vai ao médico. Quando volta muda o livro que a filha escolheu.

- Criança seleciona um livro com capa bonita, mas a mãe diz que o conteúdo é ruim e escolhe outro para a criança.

- Avó seleciona livros para levar para os netos.

- Mãe retira dois livros para a filha, pois da outra vez ela (a filha) leu em quinze minutos.

\section{Critérios para a seleção de leitura}

- Professora comenta que livros só com palavras os alunos não querem ler. É preciso ter figuras.

- A criança diz que não gosta de ler muito, só quando tem poucas letrinhas.

- Esta criança já apresenta um critério para selecionar o nível das leituras que quer ler.

- Pai gosta da capa colorida do livro e fala para a filha levar.

A visão da capa do livro é um critério que o pai utilizou para selecionar a leitura para a filha.

- Fez uma breve leitura dos livros indicados pela bibliotecária, quando solicitou a ajuda desta. 
- É importante a boa localização dos autores para facilitar a busca.

- Gostou do livro que leu e quer emprestar outro do mesmo autor.

Novamente aparece um outro critério para a seleção da leitura: ler outros livros do mesmo autor.

- Na vez anterior, marcou o lugar onde ficava o livro Estação Carandiru e foi procurar. Ficou decepcionado por não estar lá. O livro estava emprestado. Mesmo assim procurou por outro livro.

- A criança demonstra conhecer o acervo de livros infantis, que gosta de consultar.

Este é o primeiro critério: saber onde fica o acervo, cujos livros deseja ler.

- Apesar de não ter o livro que queria $A$ morte do caixeiro viajante, permaneceu no ônibus procurando outro livro.

- Não consultou outras estantes. Chega sabendo o que quer emprestar.

- Quer um livro com mais páginas do que aquele que a amiga havia Ihe mostrado.

- As crianças "lêem" vários livros-brinquedo.

Está, esta criança, despertando o seu gosto pela leitura.

- Adolescente é deficiente auditivo e interessado pela leitura.

- Criança sabe qual livro quer: não precisa procurar.

- Embora não soubesse o nome do autor, conhecia o livro (Senhora) e quis outro de José de Alencar.

- Adulta queria livros de contos de fadas, mas com letras grandes.

Esta situação está de acordo com a pesquisa realizada por Castro (1999), na qual investiga a leitura de adultos, freqüentadores de um Curso Supletivo.
- Adolescente sugere Monteiro Lobato para os amigos e diz que escolhe os livros pelo título e não pela grossura.

- Adulto não queria retirar nada, mas, com tempo, procura e encontra um livro que quer ler.

- Adulto escolhe pela quantidade de páginas. Alega que a sua vista não agüenta ler tanto.

- O pai disse ao filho que pegasse o livro que achasse melhor.

- Não quis levar um livro para o filho, dizendo que ele é quem deve escolher.

- Adolescente parece conhecer bem os autores brasileiros.

- Provavelmente, o livro que devolveu a ajudou, pois era sobre gravidez e ela está grávida (e terminando o segundo grau).

- Por ser a primeira visita ao ônibus, uma senhora solicita sugestão de títulos de Culinária.

- Depois de meia hora, retirou um livro de Literatura Infantil, volta, devolve e pega um de atividades.

- Retira livros das estantes, por oito vezes, até encontrar o qual deseja.

\section{Troca de livro entre os(as) leitores(as)}

- Um adulto controla a escolha dos outros familiares para que ele depois também possa ler.

- Um adolescente está com mais três pessoas e todos têm que pegar livros para trocarem entre si. São todos leitores habituais.

- A criança veio com quatro amigos e farão revezamento de livros.

- Adolescente veio com amigos que também escolheram material sobre esportes.

- Adolescente veio com amigos que irão fazer, entre eles, rodízio com os livros. 
- A mãe e as filhas farão rodízio com os livros.

- Mãe gostaria de levar vários livros que acha interessante. Chamou as filhas para fazer o cadastro.

- Adulto retira livros para ele, para o irmão e para a esposa, mas livros que ele gostaria de ler.

- Adulta e adolescente afirmam que os livros que foram emprestados na vez passada circularam pela família toda.

\section{Indicação de outra pessoa}

- Não escolhe o livro na estante. A amiga é quem faz isso.

- Escolhe um livro porque outra pessoa a convence a levar um.

- Pede sempre ajuda ao filho para escolher um livro.

- Não vai a outra estante. O livro que a amiga indica ela retira.

- Amigo auxilia adolescente na escolha porque ela não sabe o que é crônica.

Segundo ele são "histórias engraçadas".

\section{Não gosta de ler}

- Devolveu o livro e saiu do ônibus. Disse que não queria outro.

- Criança diz que não gosta de ler.

Faz-se necessário estabelecer um programa de leitura com as crianças, para que saibam o que é ler. No entanto, não temos a pretensão de que todos sejam leitores(as). Serão aqueles que assim desejar. Entretanto, repetimos que é necessário realizar um trabalho de leitura com os(as) usuários(as).

- Não aceita sugestão porque não quer levar outro livro.
- Adulta diz não gostar de ler. Levou a revista Crochê Especial.

- A mãe pede ajuda porque a adolescente não gosta de ler.

- Entram, saem a toda hora, pegam livros, fazem bagunça.

São poucos os que não gostam de ler, pois os que freqüentam os ônibus são os que querem gostar ou os que gostam.

\section{Conhecer o ônibus}

- Não conhecia o ônibus e, após a visita, elogiou muito.

- Viu o ônibus na rua e foi atrás para saber o que era.

- Elogia muito o ônibus e fala da importância da leitura.

- Elogiou o serviço do ônibus.

- Mãe traz a filha para conhecer o ônibus.

- O cadastro era só para os filhos, mas resolve fazer para ela também.

- Adulto veio conhecer o ônibus pensando que era para doar sangue.

- Disse gostar muito de ler e trouxe mais uma pessoa.

- O namorado mora em outro bairro e ela telefonou para ele vir conhecer o ônibus.

- "É muito bom ter o ônibus aqui. Queremos sempre estar vindo".

- Foi embora, queria apenas saber o que era o ônibus.

- Espantado disse: "ônibus de livro!"

- Após demonstrar dificuldade para lidar com as fichas de usuário, recebeu orientação de como fazê-lo.

- Um senhor elogia o acervo e sugere que em todas as bibliotecas haja alguém para auxiliar as crianças, como aconte-ce neste Projeto. 


\section{Descobertas}

- A mãe folheia vários livros e diz que irá ler o livro para a criança. A filha pergunta se ela sabe ler.

É interessante a pergunta em que a filha descobre que a mãe sabe ler. Isto revela à filha a inclusão da mãe no universo dos alfabetizados.

- Um adolescente leu o livro e agora quem está lendo é sua mãe.

A mãe descobre o interesse em ler o que o filho leu.

- As senhoras, que freqüentam o acervo de culinária, copiam as receitas dos livros e cada uma está montando um caderno.

- A criança tinha "necessidade de pegar um número grande de livros, mas não tinha paciência para ler".

Pela descrição dada pela observadora, este parece ser o primeiro contato que a criança tem com os livros. É preciso senti-lo, com os cinco sentidos, ter o contato físico com o livro para depois iniciar a leitura (HUCK, 1999; VÁLIO, 1996).

- Uma criança de 6 anos, admirada, perguntava às pessoas, que estavam dentro do ônibus, se na casa delas também têm livros e diz "que é muito legal".

- Uma senhora fica feliz, acha o Projeto lindo e diz que irá trazer os netos.

- Gosta do livro que leu e conta a história para os integrantes do ônibus.

\section{Preferências de leitura}

- Um leitor tem preferência por reforma agrária.

- Uma adolescente fica um bom tempo no ônibus lendo receitas.

- Adulta copia todos os livros de culinária.
- Adolescente diz que gosta de livro de bruxa.

- Mãe diz que a filha adora livros de fadas e de bruxas.

- Gosta de carros, esportes e animais.

- Fica lendo no ônibus revistas e gibis.

- Mostra livros de Jorge Amado que já leu e gostou.

- Antes de ir embora, vai até ao acervo de revistas e solicita livro de Fernando Pessoa.

- Pergunta pelo livro de Jô Soares.

- Gosta da Coleção Vaga-lume.

- Ficam no ônibus lendo gibis.

- Sugere títulos de Auto-ajuda.

- Volta para devolver um livro que a irmã não gostou e retira outros dois.

- Indicou livros de Seicho-noie.

- Comenta que o filho não leu porque tinha muita morte (Escaravelho do diabo).

- Outra mãe comenta que a filha está no pré e já soletra e que os livrinhos que pega, ela lê para a criança. "Isto tem ajudado muito no desenvolvimento da menina".

- Queria retirar mais de um livro e insistiu muito para isso. Por duas vezes, o ônibus já voltou ao bairro e até agora ela não devolveu o livro.

- Os amigos brincam com a situação de ter que responder perguntas que sua mãe faria sobre o livro, seguindo a orientação da professora.

Por isso, e por motivos levantados anterior-mente, o ônibus não pode estacionar perto de escola, pois as professoras passam a cobrar a leitura da criança. A Leitura em movimento é um Projeto que tem como objetivo oportunizar leitura e informações aos cidadãos.

\section{Divulgação do Projeto}

- Trouxe uma amiga para fazer o cadas-

tro. 
- Quis saber quais são os outros bairros por onde passa o ônibus para indicar aos parentes.

- Traz o filho e a esposa para fazer o cadastro.

- Uma criança trouxe mais três e todos ficaram lendo gibis sentados dentro do ônibus.

- O representante de bairro é que chamou a criança para fazer a ficha no ônibus.

- Adolescente traz duas pessoas para fazer o cadastro.

- Fez cadastro porque leu sobre o ônibus no jornal da Transurc (Transportes Urbanos de Campinas).

- É do grupo da Prefeitura "agentes de saúde". Veio conhecer o ônibus e divul-gar para os colegas.

- É motorista de ônibus e trouxe também o cobrador para conhecer o ônibus-bi-blioteca.

- Os filhos levaram a mãe para se cadastrar.

- A mãe fez cadastro e retirou um livro para a filha, que foi buscar o pai para também fazer o cadastro.

- Vai voltar para fazer o cadastro e recomendar às filhas e ao pessoal da Cooperativa da Prefeitura.

- Vai encontrar um colega, conhece o ônibus, escolhe livro de Esportes. Gosta e vai buscar os documentos para se cadastrar.

\section{Para trabalho de pesquisa}

- Não olha outros livros. Este, que retirou, é para a esposa fazer um trabalho para a escola.

- Adolescente queria mesmo era um livro para fazer trabalho de escola, de Geografia.

\section{Outros comentários}

- Disse que o livro de Kung Fu é perigoso, pois tem muito louco no mundo. Fica feliz em levar o livro do Corinthians porque é fanático pelo time.

- Adulta escolhe o livro e deixa os filhos no ônibus que, segundo ela, "demoram muito para escolher".

- A irmã quer que ele leve outro livro. A mãe disse que cada um escolhe o seu.

- Mãe não interfere na escolha do filho.

- Adolescente comenta que é muito difícil ir buscar livro na Biblioteca Pública e que ela nunca foi.

- Mãe diz ao filho que quem lê mais, escreve melhor.

- Adulta comenta que precisa de 10 anos para conseguir ler tudo que tem no ônibus.

- Como chovia, o ônibus ficou estacionado em outro lugar. A usuária telefonou para a Biblioteca Pública para confirmar se o ônibus tinha vindo. Está satisfeita com o trabalho do ônibus.

- Não gostava de ler, mas agora está adorando.

- Adulto diz que o irmão não estava no bairro e deixou a carteirinha para que ele pegasse o livro. Gostam muito do serviço do ônibus.

- Participou da entrevista que o jornal estava fazendo nesse dia no ônibus-biblioteca.

- Adolescente comenta com os amigos os livros que já leu e faz indicações.

- Adolescente trouxe uma amiga para cadastrar-se. Tem 13 anos, mas a leitura é extremamente infantil.

- Elogia o serviço do ônibus e quando não puder retirar livros irá pedir para alguém fazer isto por ela.

- Adulto conta que o filho leu a historinha para todos da família.

- Pergunta o que é culinária. Elogia o trabalho do ônibus porque irá ajudar na escola, para ler e para fazer comida que vai aprender com os livros. 
- Criança pergunta sobre o livro Culinária de A a Zque aparece na TV (a pedido da mãe).

- Diz o pai, que está acompanhado do filho: "lendo o jornal sobre esportes, conversamos sobre futebol".

- Os filhos sabem ler, mas a mãe lê para eles.

- A mãe não deixou a criança levar o livro. Selecionou dois livros para ela (mãe) ler.

- Está com uma criança menor. Retira livro da estante e dá para a criança olhar.

- Perguntam ou trazem livros para doação.

- O livro emprestado volta sujo.

- Havia uma preocupação muito grande, por parte de uma criança, em não fazer barulho. Colocava o livro com o dorso para cima, mas, às vezes, de ponta cabeça.

\section{Normas para o uso do acervo}

- Trazer documento de identidade e um comprovante de endereço.

- Se for menor de 12 anos, vir acompanhado de um adulto.

- Se atrasarem a devolução, não poderão retirar outro material de leitura.

- Se não terminaram de ler, poderão renovar o material de leitura por mais quinze dias.

- As revistas do mês corrente não poderão ser emprestadas, somente as dos meses anteriores.

\section{CON CLUSÕ E S}

É possível dizer, após as três etapas concluídas, que foram cumpridos os objetivos propostos para a pesquisa, na realização das três etapas, visibilizadas nos procedimentos metodológicos.

Na Etapa I, identificamos os bairros, onde não havia nenhum usuário. Ao realizarmos a análise desses dados, concluímos que a zona mais carente de biblioteca é a Sudoeste do Município de Campinas.

Deste estudo selecionamos 10\% daqueles bairros onde não há usuários da Rede de Bibliotecas Públicas de Campinas. Assim, chegamos ao total de 40 bairros selecionados, sendo a maior parte deles pertencentes à Zona Sudoeste.

Da Zona Norte da cidade, não selecionamos nenhum bairro, pois é justamente nesta região que estão localizadas a Unicamp e a PUC-Campinas.

Concluímos também que a seleção dos bairros está de acordo com o propósito principal desta pesquisa, que é oportunizar aos participantes o exercício de sua cidadania, tendo a leitura como prática. Além disso, foi nosso compromisso concretizar a investigação durante a prestação de serviços (Etapa III), caracterizando-se como uma pesquisa participante.

Se por um lado, objetivamos conhecer as necessidades e interesses de leitura da comunidade pesquisada, por outro, como resultado, estabelecemos os critérios de seleção dos acervos.

Desses critérios, rigorosamente respeitados, adquirimos os acervos adequados às necessidades e interesses de leitura dos cidadãos moradores dos bairros escolhidos, tendo em vista os ledores de Literatura e de textos informativos. Conseguimos, desse modo, conhecer os assuntos que podem constituir os acervos de bibliotecas setoriais.

Com o Programa de atendimento ao cidadão/leitor, cumprimos o último objetivo, elaborado para a Etapa III do Projeto de Pesqui- 
sa. Da eficiência do trabalho de atendimento, podemos dizer, com certeza, que as pessoas, freqüentadoras dos ônibus, têm tido prazer em ler, em ir buscar material de leitura e sempre voltar para trocar por outro. As crianças têm sido até afoitas em ler, ficando grande parte delas, dentro ou fora, sentadas lendo o tempo todo da estadia dos ônibus. Gostam de ler! São leitores(as)!

Os adolescentes também têm estado lendo jornais, revistas, livros, retirando e devolvendo esses materiais de leitura, mostrando o desejo e o prazer de ler.

Os adultos, homens e mulheres, freqüentam os ônibus assiduamente, retirando, trocando, devolvendo, indo a outros bairros, com muita vontade de ler novos jornais, novas revistas, novos livros, ficando, muitas das vezes, dentro dos ônibus, em pé lendo.

Pelas manifestações dos amantes da leitura, meninos, meninas, adolescentes, adultos, adultas, senhoras e senhores idosos, estamos convictos de que este Projeto está oportunizando (porque a Instituição Parceira continua desenvolvendo o Projeto) a todos eles o exercício da leitura como prática de cidadania. Dizemos: estamos convictos, porque as nossas observações, registradas nos roteiros de observações, comprovaram a nossa convicção.

\section{REDE DE BIBLIOTECAS PÚ B LICAS DE CAM PINAS: POLÍTICAS PÚ BLICAS}

Apresentamos à Instituição Parceira, a Prefeitura Municipal de Campinas, os modos de ação provenientes da Pesquisa, para que se estabeleçam as Políticas Públicas com relação à oportunidade dos moradores de bairros periféricos poderem ter acesso às Bibliotecas Públicas, com vistas à educação continuada e, portanto, poderem ter direito ao exercício de sua cidadania.

Para sugerir à Instituição Parceira, a Prefeitura Municipal de Campinas, um Projeto de Políticas Públicas, com respeito à Rede de Bibliotecas Públicas de Campinas, colocamos, em primeiro lugar, a necessidade de dar continuidade e prioridade a este Programa de atendimento ao cidadão/leitor, prestado pelos dois ônibus-biblioteca.

Construir bibliotecas setoriais nos bairros mais carentes de informação, principalmente naqueles que já possuem usuários da biblioteca Leitura em movimento.

Constituir os acervos, tendo como base esta pesquisa e de acordo com novas investigações sobre os assuntos preferidos dos moradores.

Para a construção de bibliotecas setoriais, selecionamos, do ônibus 2, os 10 bairros que têm maior incidência de usuários. Desse modo, indicamos como prioridade a construção de bibliotecas setoriais, inicialmente, seguindo a ordem decrescente de freqüência de usuários dos 10 primeiros bairros: $1^{\circ}$ Vila Nilza; $2^{\circ}$ Jardim Itaguaçu II; 3o Jardim São Diego; 4ํC Cidade Singer; $5^{\circ}$ Country Ville; 6ำ Vila Lovato (São João); 7ํJardim do Lago II; 8ํJardim Campo Belo IV; 9ํVila Campos Salles; $10^{\circ}$ Vila Maísa.

O ônibus 1 teve problemas mecânicos e as chuvas também prejudicaram a ida aos bairros, pois estes não eram asfaltados. Mesmo assim, foi possível coletar os dados, pois o ônibus circulou durante três meses. De acordo com a freqüência dos usuários, classificamos os bairros em ordem decrescente, conforme pode ser lido: 1 ํ Jardim Metanópolis; 2 ํ Jardim

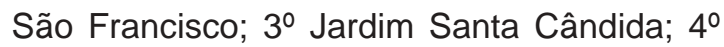
Chácara Três Maria; 5ำ Jardim Márcia; 6ํVila

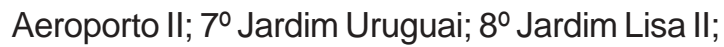
9 ํㅡㄴ Vila Lunardi; $10^{\circ}$ Dic IV. 


\section{RE FER Ê N CIAS}

ARAÚJO, E.A. Informação, cidadania e sociedade no Brasil. Informação \& Sociedade: Estudos, João Pessoa, v.2, n.1, p.67-77, 1992.

BAPTISTA, I. Educador social: especialistas de mãos vazias. Jornal "A Página da Educação", Porto, v.9, n.94, p.19, 2000. Disponível em: <http:// www. apagina.pt/arquivo/Artigo.asp?|D=1155>. Acesso em: 2 mar. 2004.

BAMBERGER, R. Como incentivar o hábito da leitura. São Paulo: Cultrix, 1977. p.17.

BARBOSA, L.C. A exclusão pela leitura. Extra Classe, Porto Alegre, v.4, n.29, 1999. Disponível em: $<$ http://www.sinpro-rs.org.br/extra/mar99. educa1.htm>. Acesso em: 2 mar. 2004.

BRIGGS, S. The social value of the library: or you can't take a computer to bed. Disponível em: <http:// www.sInsw.gov.au/plp/gilgand/value.htm>. Acesso em: 17 fev. 1999.

CARVALHO, L.M. Biblioteca, instituição preservadora da cultura dominante? Informação \& Sociedade: Estudos, João Pessoa, v.1, n.1, p.33-43, 1991.

CASTEL, R. A dinâmica dos processos de marginalização: da vulnerabilidade a desfiliação. Caderno CHR, Salvador, n.26/27, jan./dez. 1997.

CASTEL, R. As metamorfoses da questão social: uma crônica do salário. Petrópolis: Vozes, 1998.

CASTEL, R. Intervention de Robert Castel. In: CONFÉRENCE SUR L'AVENIR DU TRAVAIL, DE EMPLOI ET DE LA PROCTENTION SOCIALE, 2001, Annecy. Anais... Disponível em: http://www.ilo.org/ public/french/bureau/inst/papers/confrnce/ annecy2001/discuss/castel.htm. Acesso em: 02 mar. 2004.

CASTRO, C.A. Leitura de adultos com escolaridade tardia. São Luís: UFMA, 1999. 118p.

DECRETO Presidencial n.520 de 13 de maio de 1992. Legislação Federal, p. 196-197.

HUCK, C.S. Children's Literature in the elementary schools. 5th.ed. New York: Holt Rinehart and Winston, 1999. 914p.

IRELAND. Ministry for the Environment and Local Government. Dempsey Launches major report on
Public Library Service. Nov. 1998. Disponível em: $<\mathrm{http}: / /$ www.environ.ie/press/publib.html>. Acesso em: 18 fev. 1999.

LIBRARY Association (UK). Public Library Policy Review. Disponível em: <http://www.la-hq.org.uk>. Acesso em: 12 fev. 1999.

LIBRARY Council (Ireland). National Policy on Libraries and Information Service. Disponível em: <http://homepages.iol.ie/ libcoun/policy.htm>. Acesso em: 17 fev. 1999.

LIMA, L.O. Estórias da educação no Brasil: de Pombal a Passarinho. Brasília: Editora Brasília, 1974.

PENSADO, A.G. Las bibliotecas públicas para niños en Cuba. Disponível em: <http://ifla.inist.fr/IV/ ifla60/60-guep.htm>. Acesso em: 20 fev. 1999.

RABELO, O.C.P. Da biblioteca pública à biblioteca popular: análise das contradições de uma trajetória. Revista da Escola de Bibliotecononomia da UFMG. Belo Horizonte, v.16,n.1, p.19-42, 1987.

RIBEIRO, M. Educação para a cidadania. Educação e Pesquisa, São Paulo, v.28, n.2, p.113-129, 2002.

RIZZO, S. O país que não lê. Revista de Educação, São Paulo, v.25, n. 207, p.30-38, 1998.

SILVA, L.A.G. Políticas e programas de informação e documentação da Unesco e fontes para seu estudo. Informação \& Sociedade: Estudos, João Pessoa, v.4, n.1, p. 93-118, 1994.

SILVA, T.E. As regras do jogo. Políticas culturais: do mecenato ao neo-liberalismo. Informação \& Sociedade: Estudos, João Pessoa, v.3, n.1, p. 42-52, 1993.

SISTEMA NACIONAL DE BIBLIOTECAS PÚBLICAS. Ministério da Cultura. Fundação Biblioteca Nacional. Rio de Janeiro. Departamento de Processos Técnicos, s/d.

SUAIDEN, E.J. Biblioteca pública brasileira: desempenho e perspectivas. São Paulo: LISA; Brasília: INL, 1980.

SUAIDEN, E.J. Biblioteca pública e informação à comunidade. São Paulo: Global, 1995. (Coleção Ciência da Informação). 
UNIVERSIDADE DO CHILE. Centro de Análisis de Políticas Públicas. Descripción del Centro. Disponível em: <http://www.capp.uchile.cl/Capp1. $\mathrm{html}$. Acesso em: 12 fev. 1999.

UNIVERSIDADE DO CHILE. Centro de Análisis de Políticas Públicas. Programa de Gobierno y Políticas Públicas. Disponível em: <http://www.capp. uchile.cl/Capp3.html>. Acesso em: 12 fev. 1999.

VÁLIO, E.B.M. Leitura: uma prioridade nas instituições inglesas e escocesas. Revista da Escola de Biblioteconomia da UFMG, Belo Horizonte, v.16,n.1, p. 84-96, 1987.

VÁLIO, E.B.M. Biblioteca Escolar: uma visão histórica. Transinformação, Campinas, v.2, n.1, p.15-24, 1990.
VÁLIO, E.B.M. Múltiplas leituras: a formação de leitores. In: SEMINÁRIO NACIONAL SOBRE LITERATURA INFANTO-JUVENIL, LIVRO DIDÁTICO \& PARTICIPAÇÃO DA COMUNIDADE NA FORMAÇÃO DE LEITORES, 1996, São Paulo. Anais... São Paulo: Fatema, 1996. p. 450-457.

VÁLIO, E.B.M. et al. Biblioteca Pública: a questão dos interesses de leitura como indicadores de critérios para a seleção e aquisição de acervos. In: ENCONTRO NACIONAL DE PESQUISA EM CIÊNCIA DA INFORMAÇÃO: INFORMAÇÃO, CONHECIMENTO E TRANSDISCIPLINARIDADE, 5., 2003, Belo Horizonte. Anais... Belo Horizonte: UFMG, 2003. 1 CD-ROM. 


\section{ANEXO 1}

\section{ROTEIRO DE ENTREVISTA: INTERESSES DE LEITURA}

Campinas / 2002

Bairro:

R./Av.: no:, Compl.:

№ de pessoas na casa: Sujeito:

Nome:

Idade:

Sexo: $\quad(F)$

(M)

Escolaridade: (sem escolaridade)

(1ํ.i) $\left(1^{\circ} . \mathrm{c}\right)$

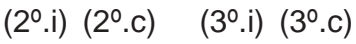

Profissão:

Onde trabalha/estuda:

1 - 0 que você gosta de receber como presente?
( ) chocolates
( ) flores
( ) livros
( ) perfumes
( ) jogos
( ) jóias
( )
( ) roupas
( ) viagens
( )

2 - O que você mais gosta de fazer?

3 - Você gostaria de saber mais sobre:

3.1 - ( ) arquitetura, decoração, jardinagem?

3.2 - ( ) artesanato?

3.3 - ( ) assuntos científicos, descobertas, planetas?

3.4 - ( ) biografia, história da vida de pessoas?

3.5 - ( ) bordados, costura, crochê, desfiles, moda, tricô?

3.6 - ( ) ecologia, meio ambiente?

3.7 - ( ) esportes? Qual / quais?

3.8 - ( ) informática?

3.9 - ( ) receitas de comida?

3.10 - ( ) vida de gente famosa?

3.11 - ( ) algo mais? O quê?

\section{4 - Você lê/vê:}

( ) jornal? Que assunto?

Com que freqüência?

( ) compra

( ) toma emprestado

( ) ganha

( ) revista?

Que assunto?

Com que freqüência?

( ) compra

( ) toma emprestado

( ) livro

de

( ) auto-ajuda

( ) esotérico

literatura

( ) humor

( ) policial

( )

Com que freqüência?

( ) ganha

( ) aventura

( ) ficção científica

( ) infantil

( ) suspense

( )

( ) hist. de amor

( ) poesia

( ) terror

( )

Que assunto?

Com que freqüência?

( ) compra

( ) toma emprestado ( ) ganha 
5 - Você já foi a uma biblioteca? ( ) sim não

5.1 - Qual/Quais?

5.2 - Onde fica $(\mathrm{m})$ ?

5.3 - Você já emprestou livros dessa(s) biblioteca(s)? $\quad(\quad) \operatorname{sim} \quad(\quad)$ não

5.4 - Qual foi a última vez que você foi a uma Biblioteca?

5.5 - Qual é a Biblioteca mais próxima daqui?

5.6 - Qual é a de mais fácil acesso? Por quê?

5.7 - O que você pode encontrar de seu interesse em uma Biblioteca?

5.8 - Qual é a sua opinião sobre Biblioteca?

5.9 - Se houvesse uma Biblioteca neste bairro você freqüentaria?

( ) $\operatorname{sim}($ ) não ( ) talvez

Para quê / Por quê?

5.10 - Em que local ela deveria ficar para ser de fácil acesso para todos do bairro? 


\section{ANEXO 2 \\ ROTEIRO DE OBSERVAÇÃO}

BAIRRO

DATA

SUJEITO №

Objetivo: avaliar o uso e a disseminação do acervo.

1. Como se comporta o participante nas seguintes etapas?
a) Chegada:
b) Acesso ao acervo:
c) Ação:

2. Tipo de acervo escolhido:

3. Na hora da devolução, o participante manifesta satisfação ou descontentamento em relação ao material utilizado?

4. Observações: 